\title{
Evaluation of Physicochemical, Microbiological and Polycyclic Aromatic Hydrocarbon Content of Top Soils from Oka Market Waste Collection Site, Benin City, Nigeria
}

\author{
*11MARHIAGBE, EE; ${ }^{1}$ OSARENOTOR, O; ${ }^{1}$ OBAYAGBONA, ON; \\ ${ }^{1}$ EGHOMWANRE, AF; ${ }^{1}$ NZEADIBE, BN
}

\author{
Department of Environmental Management and Toxicology, \\ Faculty of Life Sciences, University of Benin, Nigeria \\ Email: esosa.imarhiagbe@uniben.edu/+2347034482706
}

\begin{abstract}
The aim of this study was to evaluate the physicochemical, microbiological and polycyclic aromatic hydrocarbon composition of top soil samples from Oka market waste collection site. Standard analytical and microbiological procedures were adopted. $\mathrm{pH}$ and electrical conductivity ranged from 6.45 to 7.39 and 230 to $940 \mu \mathrm{S} / \mathrm{cm}$ respectively. The highest content of organic carbon was observed in sample $2(5.91 \%)$, while that of sodium and potassium were $2.44 \mathrm{meq} / 100 \mathrm{~g}$ (soil 2) and $0.23 \mathrm{meq} / 100 \mathrm{~g}$ (soil 3) respectively. Calcium and magnesium content in the soil ranged from 2.60 to $7.72 \mathrm{meq} / 100 \mathrm{~g}$ and 0.69 to $1.38 \mathrm{meq} / 100 \mathrm{~g}$ respectively. The total hydrocarbon content ranged from 2.4 to $15.9 \mathrm{mg} / \mathrm{kg}$. The results of particle soil analysis revealed high content of sandy soil (88.2 to 90.7). Iron had the highest concentration among studied heavy metals, ranging from 193 to $649.2 \mathrm{mg} / \mathrm{kg}$. Total heterotrophic bacterial and fungal counts were in the magnitude of $10^{4}$, ranging from 3.6 to 17.4 cfu/g and 2.3 to $6.9 \mathrm{cfu} / \mathrm{g}$. Tentative bacterial isolates were Bacillus sp., Micrococcus sp., Staphylococcus spp. and Enterobacter sp., while fungal isolates were Aspergillus sp. Candida sp. and Penicillium spp. The highest concentration of Polycyclic Aromatic Hydrocarbon was $16.5 \mathrm{mg} / \mathrm{kg}$, with its components ranging from $0.08 \mathrm{mg} / \mathrm{kg}$ (Dibenzo(a,h) anthracene) to 2.1 $\mathrm{mg} / \mathrm{kg}$ (Benzo(k) fluoranthene). The quality of soil is as a result of all the processes that act on it, therefore, informing the public of the dangers inherent in improper management of soil environment should be considered as an important aspect of scientific research. () JASEM
\end{abstract}

\section{http://dx.doi.org/10.4314/jasem.v21i1.12}

Keywords: market, physicochemical, microbial, PAHs, waste, heavy metals

Soil is the naturally occurring, unconsolidated or loose covering on the earth's surface. Soil is made up of broken rock particles that have been altered by chemical and environmental conditions, such as weathering and erosion. Soil is a mixture of mineral and organic constituents that are in solid, gaseous and aqueous states (Fawole and Oso, 2001). Soil bacteria and fungi play pivotal roles in various biogeochemical cycles (BGC) and are responsible for the cycling of organic compounds. Soil microorganisms also influence above-ground ecosystems by contributing to plant nutrition, soil structure, texture and fertility (Fawole and Oso, 2001). With urban industrialization, social development and population increases, solid waste production are growing rapidly, making pollution a serious problem. If not properly disposed and managed the resulting environmental impact from these wastes can be disastrous (Obi, 2000). Some of the obvious consequence of man-made pollution includes transmission of diseases by water borne pathogens, accumulation of toxic or recalcitrant chemicals in the soil, destabilization of ecological balance and negative effects on human health.

Researches have shown that improper waste disposal means have negative consequences on the receiving environment with regards to public health, and local economies (Abduls-Salam, 2009). The heavy metal concentration and microbial pollution of soils in market dumpsite have been investigated in many cities of Nigeria, Uyo (Ogbemudia and Mbong, 2013), Sokoto (Rabah and Ibrahim, 2010), Umuahia (Eze et al., 2013) and Delta state (Akpoveta et al., 2010), indicating large amounts of anthropogenic inputs. Dumpsite is an old traditional method of waste disposal similar to landfill method of waste management (Osazee et al., 2013). They are often established in disused quarries or evacuated pits away from residential areas (Abduls-Salam, 2009). Market dump sites accommodate a lot of waste with different constituent materials, including organic materials (plant and animal waste) and hydrocarbons. These wastes are colonized by microorganisms, including fungi and bacteria, carrying out degradation and transformation of degradable (organic) materials

*correspondence authour Email: esosa.imarhiagbe@uniben.edu/+2347034482706 
(Osazee et al., 2013). Osazee et al. (2013) has earlier observed that wastes are generally dumped in approved and non-approved dump sites across Benin City, Edo State, with waste composition of these dump sites ranging from hospital, residential, commercial and market etc. The aim of this study was to investigate the physicochemical qualities, polycyclic aromatic hydrocarbons and microbiological pattern of the top soils from Oka market waste collection site, Ikpoba-Okha Local Government Area of Edo State, Nigeria.

\section{MATERIALS AND METHODS}

Study Areal Sample collection: The study area was the Oka market waste collection site, located at Ikpoba-Okha Local Government Area of Edo State (Fig 1). Duplicate soil samples were collected from different locations at the dump site with the aid of a soil augar and was packed in sterile polybags and transferred to the laboratory for analysis.

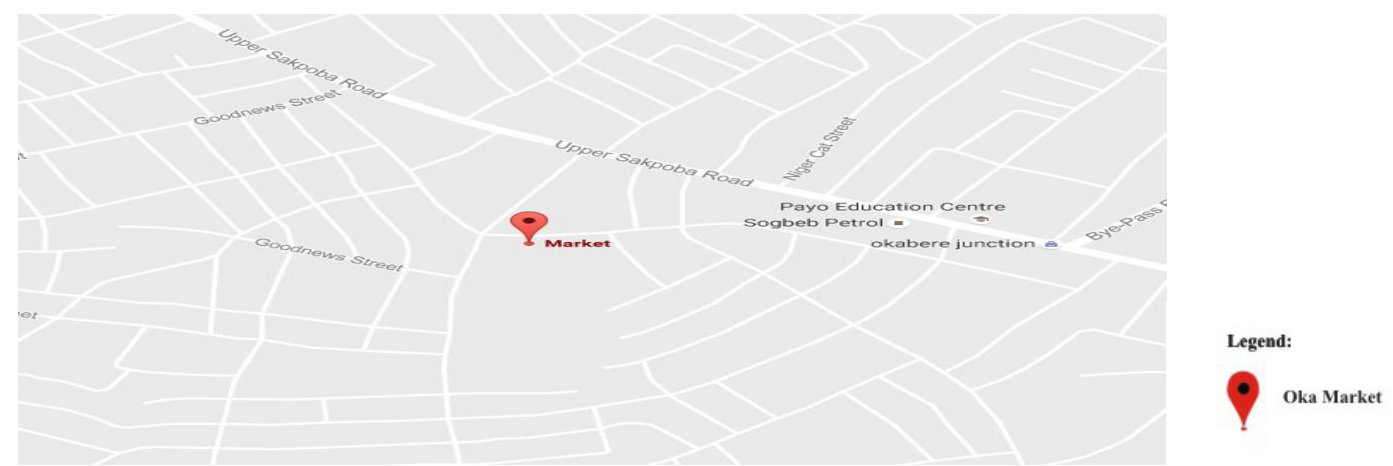

Fig 1: Map of studied location showing Oka market Credit: Google

Physicochemical parameters: Samples were prepared analysed for $\mathrm{pH}$, electrical conductivity, organic carbon, cation exchangeable bases, total hydrocarbon content, ammonium-nitrogen, nitrate, sulphate, particle size distribution according to Onyeonwu, (2000).

Determination of heavy metals: The samples were digested using nitric acid at $105^{\circ} \mathrm{C}$ for 45 minutes after which it was allowed to cool to room temperature. The cooled digest were washed into a standard volumetric flask and were made up to the mark with distilled water (Onyeonwu, 2000). The heavy metals $(\mathrm{Pb}, \mathrm{Cd}, \mathrm{Mn} \mathrm{Fe}, \mathrm{Cu}, \mathrm{Cr}, \mathrm{Ni}, \mathrm{V}$ and $\mathrm{Zn}$ ) levels were analyzed using an Atomic Absorbance Spectrophotometer (AAS) (MODEL-SOLAAR 969 UNICAM SERIES).

Determination of polycyclic aromatic hydrocarbons $(P A H s)$ : Ten grams of soil samples were weighed into a solvent rinsed beaker and $50 \mathrm{ml}$ of 50:50 mixtures of acetone and dichloromethane (DCM) was added. The samples were spiked with $1 \mathrm{ml}$ of a surrogate mixture (orthoterphenyl-OTP) and placed in a sonicator for 15 minutes at $20^{\circ} \mathrm{C}$. Ten (10) grams of anhydrous sodium sulphate was then added to the sample and allowed to stand until a clear extract developed and was decanted. One milliliter $(1 \mathrm{ml})$ of the extracted samples was dissolved in n-hexane (HPLC grade) in order to elute the aliphatic hydrocarbons. The eluted samples were concentrated using rotatory evaporator to about $3 \mathrm{ml}$ and was transferred into a teflone lined screwed vial and labeled for gas chromatography (GC) for PAH analysis using Gas Chromatography (Agilent, Hewlett Packard 6890 series).

Enumeration and isolation of heterotrophic bacteria and fungi using general purpose media: Ten (10) grams of respective soil samples were suspended in ninety $(90 \mathrm{ml})$ milliliter of sterilized nutrient broth in a conical flask. The soil suspension was thoroughly mixed and serially diluted using tenfold dilution. Appropriate dilutions were plated in duplicates on sterile nutrient agar and potato dextrose agar for total heterotrophic bacterial counts and total heterotrophic fungal counts respectively. The potato dextrose agar plates were made selective for fungal growth by the addition of $1 \mathrm{ml}$ of antibiotic solution (chloramphenicol) prior to addition of the molten medium. The agar plates were incubated aerobically at $35{ }^{\circ} \mathrm{C}$ for $48 \mathrm{hrs}$ and 5 days at room temperature $\left(28^{\circ} \mathrm{C} \pm 5^{\circ} \mathrm{C}\right)$ for 5 days for bacteria and fungi respectively. After incubation, counts obtained from culture plates were recorded and expressed as the colony forming unit per gram $(\mathrm{cfu} / \mathrm{g})$ of the original sample. The various isolates were further identified and characterized (Barnett and Hunter, 1975; Cullimore, 2000; Cheesbrough, 2006). 
Multivariate data analysis: The data obtained were subjected to descriptive statistical analysis such as mean, while the PAH data soils were further subjected to principal component analysis using PAST software.

\section{RESULTS AND DISCUSSION}

Results of physiochemical parameters are presented in table 1. Evaluated soil samples in the study had $\mathrm{pH}$ and electrical conductivity ranging from 6.45 to 7.39 and 230 to $940 \mu \mathrm{S} / \mathrm{cm}$ respectively. The highest level of organic carbon was observed in sample $2(5.91 \%)$, while sodium and potassium were $2.44 \mathrm{meq} / 100 \mathrm{~g}$ (location 2) and $0.23 \mathrm{meq} / 100 \mathrm{~g}$ (soil 3) respectively. Also, calcium and magnesium content in the soil ranged from 2.60 to $7.72 \mathrm{meq} / 100 \mathrm{~g}$ and 0.69 to 1.38 meq/ $100 \mathrm{~g}$ respectively. The total hydrocarbon content ranged from 2.4 to $15.9 \mathrm{mg} / \mathrm{kg}$. The results of particle soil analysis revealed high content of sandy soil (88.2 to 90.7). These qualities may not be unconnected with the build-up and breakdown of the waste generated in the market. $\mathrm{pH}$ is an important soil property, having great effects on solute concentration and absorption in soil (Akpoveta et al., 2010; Voroney, 2007). Soils with acidic pH levels tend to have an increased micronutrient solubility and mobility as well as increased heavy metal concentration (Odu et al., 1985). The levels of exchangeable cations $\left(\mathrm{Na}^{+}, \mathrm{K}^{+}, \mathrm{Ca}^{2+}, \mathrm{Mg}^{2+}\right)$ is a reflection of soil condition with regards to the agricultural potential of soil at the study sites. Nitrogen is an important constituent of protein and nucleic acid and most microorganisms and plants take up inorganic nitrogen as nitrate $\left(\mathrm{NO}_{3}{ }^{-}\right)$or ammonium $\left(\mathrm{NH}_{4}^{+}\right)$ions.

The results of the heavy metal composition of the soil samples are shown in table 2. Iron had the highest concentration, ranging from 193 to $649.2 \mathrm{mg} / \mathrm{kg}$. Manganese ranged from 0.2 to $3.1 \mathrm{mg} / \mathrm{kg}$; copper and lead ranged from 0.1 to $1.1 \mathrm{mg} / \mathrm{kg}$ and 0.0 to 0.5 $\mathrm{mg} / \mathrm{kg}$ respectively. Chromium, zinc, cadmium, nickel and vanadium were not detected. The presence of heavy metals in an ecosystem has been observed to be of far-reaching implications to the biota and man (Gbadebo et al., 2010). The continuous entry of these metals into the surrounding environment can result in serious contamination (Imarhiagbe et al., 2015). According to USDA NRCS (2000), excess of heavy metal accumulation in soils and water bodies are toxic to humans and other animals; exposure to heavy metals is normally chronic (exposure over a longer period of time), due to food chain transfer. Acute (immediate) poisoning from heavy metals is rare through ingestion or dermal contact, but is possible. Chronic problems that are associated with long-term heavy metal exposures include mental lapse, organ failures (kidney, liver and gastrointestinal tract) and skin poisoning.

Table 3 shows the microbial diversity of the dump site soil samples. Total heterotrophic bacterial and fungal counts ranged from 3.6 to $17.4 \times 10^{4} \mathrm{cfu} / \mathrm{g}$ and 2.3 to $6.9 \times 10^{4} \mathrm{cfu} / \mathrm{g}$. The high population count of bacteria is a clear indication that the investigated soil environment is conducive for microbial proliferation and biological activity leading to a more rapid decomposition of organic matter at this dumpsite. The arrays of bacterial isolates from this study include Bacillus spp., Micrococcus sp, Staphylococcus spp. and Enterobacter sp. which are of public health significance (Imarhiagbe et al., 2015). The resident fungal species in contaminated soil were mainly the Aspergillus spp. and Penicillium spp. These fungal isolates are well known soil inhabiting microorganisms as well as common spoilage organisms (Eze et al., 2013).

The result of PAH (table 4) showed that the highest PAH concentration was $16.5 \mathrm{mg} / \mathrm{kg}$ for sample 4 . While the PAH component levels ranged from 0.08 $\mathrm{mg} / \mathrm{kg}$ (Dibenzo(a,h) anthracene) to $2.1 \mathrm{mg} / \mathrm{kg}$ (Benzo (k) fluoranthene). There are reports indicating that incomplete combustion of indiscriminate dumping of refuse along major roads, within residential areas and in market places, result in aesthetic pollution and emits repulsive odour due to decomposing waste (Abranjano et al., 2003). The heavy molecular weight (HMW) PAHs consist of 4 to 6 aromatic rings and are less readily biodegraded by indigenous microorganisms hence can persist in the soil environment. From this study, nine (9) out of the sixteen (16) polycyclic aromatic hydrocarbon (PAHs) classified problematic components were detected in the collected samples, with fluorene and phenanthrene in locations 3 and 4 having the highest concentration $(1.20 \mathrm{mg} / \mathrm{kg}$ and $3.3 \mathrm{mg} / \mathrm{kg}$ respectively). The absence of naphthalene, acenaphthylene and acenaphthene, suggest that the 2 to 3 ring structural molecule may have been degraded probably by the resident soil microorganisms or any other means. Application of principle component analysis (Fig 2), shows that there was a remarkable difference between the control and soil samples by the variation in their PAHs compositions. In component 1(the horizontal axis), only soil sample 4 had positive correlation for the PAHs while component 2, (vertical axis) the control, sample 3 and 4 showed positive correlation for the PAHs.

Conclusion: Soil is basically the primary recipient of daily generated wastes at the market and the quality of soil is as a result of all the chemical and biological 
processes (including anthropogenic processes) that act on it. The effect of these wastes on the soil ecosystem is not surprising considering the tendency for pollutants to alter soil quality. Therefore, informing the public of the dangers inherent in improper management of soil environment should be considered as an important aspect of scientific research and awareness.

Table 1: Physiochemical properties of soil used for the present study

\begin{tabular}{llllll}
\hline & Soil 1 & Soil 2 & Soil 3 & Soil 4 & Control \\
\hline $\mathrm{pH}$ & 6.74 & 6.92 & 7.39 & 6.45 & 5.78 \\
$\mathrm{EC}(\mu \mathrm{S} / \mathrm{cm})$ & 790 & 730 & 940 & 830 & 230 \\
$\mathrm{Org} . \mathrm{C}(\%)$ & 5.58 & 5.91 & 4.28 & 3.66 & 2.38 \\
$\mathrm{Na}(\mathrm{meq} / 100 \mathrm{~g}$ of soil) & 1.96 & 2.44 & 1.31 & 1.33 & 0.94 \\
$\mathrm{~K}(\mathrm{meq} / 100 \mathrm{~g}$ of soil) & 0.16 & 0.21 & 0.23 & 0.21 & 0.09 \\
$\mathrm{Ca}(\mathrm{meq} / 100 \mathrm{~g}$ of soil) & 5.83 & 7.72 & 5.38 & 5.82 & 2.60 \\
$\mathrm{Mg}(\mathrm{meq} / 100 \mathrm{~g}$ of soil) & 1.21 & 1.38 & 0.85 & 0.77 & 0.69 \\
$\mathrm{NH}_{4} \mathrm{~N}(\mathrm{mg} / \mathrm{Kg})$ & 9.42 & 13.7 & 5.34 & 3.86 & 1.53 \\
$\mathrm{NO}_{3}(\mathrm{mgKg})$ & 18.5 & 11.1 & 8.94 & 6.13 & 1.76 \\
$\mathrm{THC}^{(\mathrm{mgKg})}$ & 15.9 & 10.3 & 14.9 & 17.1 & 2.4 \\
$\mathrm{SO}_{4}(\mathrm{mgKg})$ & 8.80 & 7.63 & 2.10 & 1.95 & 1.03 \\
$\mathrm{Clay}(\%)$ & 7.8 & 8.2 & 7.8 & 8.2 & 6.8 \\
$\mathrm{Silt}(\%)$ & 2.7 & 1.6 & 2.7 & 3.6 & 2.5 \\
Sand $(\%)$ & 89.5 & 90.2 & 89.5 & 88.2 & 90.7 \\
\hline
\end{tabular}

Key: Over all mean values, EC: Electrical conductivity, Org.C: Organic carbon, Na: sodium, K: potassium, Ca: calcium, Mg: magnesium, THC: Total hydrocarbon content.

Table 2: Heavy metal properties of soil used for the present study

\begin{tabular}{llllll}
\hline & Soil 1 & Soil 2 & Soil 3 & Soil 4 & Control \\
\hline $\mathrm{Fe}$ & 649.2 & 588.9 & 764 & 806 & 193 \\
$\mathrm{Mn}$ & 3.1 & 2.0 & 0.5 & 2.4 & 0.2 \\
$\mathrm{Zn}$ & 0.0 & 0.0 & 0.0 & 0.0 & 0.0 \\
$\mathrm{Cu}$ & 0.3 & 1.1 & 1.01 & 0.25 & 0.1 \\
$\mathrm{Cr}$ & 0.0 & 0.0 & 0.0 & 0.0 & 0.0 \\
$\mathrm{Cd}$ & 0.0 & 0.0 & 0.0 & 0.0 & 0.0 \\
$\mathrm{~Pb}$ & 0.4 & 0.5 & 0.1 & 0.1 & 0.0 \\
$\mathrm{Ni}$ & 0.0 & 0.0 & 0.0 & 0.0 & 0.0 \\
$\mathrm{~V}$ & 0.0 & 0.0 & 0.0 & 0.0 & 0.0 \\
\hline
\end{tabular}

Key: Over all mean values, Fe: iron, Mn: manganese, $\mathrm{Zn}$ : zinc, $\mathrm{Cu}$ : copper, $\mathrm{Cr}$ : chromium, $\mathrm{Cd}$ : cadmium, $\mathrm{Pb}$ : lead, Ni: nickel, V: vanadium.

Table 3: Microbial analysis of soil sample used for the present study

\begin{tabular}{|c|c|c|c|c|}
\hline Sample Code & $\begin{array}{l}\text { Total Heterotrophic } \\
\text { Bacterial count } \\
\left(\mathrm{cfu} / \mathrm{g} \times 10^{4}\right)\end{array}$ & $\begin{array}{l}\text { Total Fungal count } \\
\left(\mathrm{cfu} / \mathrm{g} \times 10^{4}\right)\end{array}$ & Tentative Bacterial isolates & Tentative Fungal isolates \\
\hline Soil 1 & 15.8 & 5.1 & $\begin{array}{ccc}\text { Bacillus } & \text { spp., } & \text { Enterobacter } \\
\text { sp., } & \text { Micrococcus } & \text { sp., } \\
\text { Staphylococcus } \mathrm{spp} & \end{array}$ & $\begin{array}{l}\text { Aspergillus } \\
\text { Penicillium spp }\end{array}$ \\
\hline Soil 2 & 9.5 & 2.6 & $\begin{array}{l}\text { Bacillus spp. ,Staphylococcus } \\
\text { spp.,Micrococcus sp., }\end{array}$ & $\begin{array}{l}\text { 4spergillus } \\
\text { Penicillium } \mathrm{sp}\end{array}$ \\
\hline Soil 3 & 11.4 & 4.0 & $\begin{array}{l}\text { Bacillus sp., Enterobacter } \\
\text { sp., Micrococcus sp. }\end{array}$ & $\begin{array}{l}\text { Aspergillus } \\
\text { Penicillium spp }\end{array}$ \\
\hline Soil 4 & 17.4 & 6.9 & $\begin{array}{l}\text { Bacillus sp., Enterobacter } \\
\text { sp., Micrococcus } \mathrm{sp} .\end{array}$ & $\begin{array}{l}\text { Aspergillus sp., Candida } \\
\text { sp., Penicillium spp. }\end{array}$ \\
\hline Control & 3.6 & 2.3 & Bacillus sp., & Aspergillus spp \\
\hline
\end{tabular}


Over all mean value

\begin{tabular}{|c|c|c|c|c|c|}
\hline \multicolumn{6}{|c|}{ Sample Code } \\
\hline PAH Components & Soil 1 & Soil 2 & Soil 3 & Soil 4 & Control \\
\hline & & $\mathrm{mg} / \mathrm{kg}$ & & & \\
\hline Naphthalene & 0 & 0 & 0 & 0 & 0 \\
\hline Acenaphthylene & 0 & 0 & 0 & 0 & 0 \\
\hline Acenaphthene & 0 & 0 & 0 & 0 & 0 \\
\hline Fluorene & 0 & 0 & 1.20 & 3.3 & 0 \\
\hline Phenanthrene & 0 & 0 & 1.20 & 1.7 & 0 \\
\hline Anthracene & 0 & 0 & 0 & 0 & 0 \\
\hline Fluoranthene & 1.60 & 0 & 0.6 & 6.8 & 0 \\
\hline Pyrene & 0 & 0 & 1.0 & 1.7 & 0 \\
\hline 1,2-Benzothracene & 0 & 0 & 0 & 0 & 0 \\
\hline Chysene & 1.70 & 0 & 0.30 & 4.4 & 0.14 \\
\hline Benzo(b)fluoranthene & 0 & 0 & 0 & 0 & 0 \\
\hline Benzo(k)fluoranthene & 0 & 2.0 & 0 & 0 & 0 \\
\hline Benzo(a)pyrene & 1.50 & 0.50 & 0.6 & 2.1 & 0 \\
\hline Dibenzo(a,h)anthracene & 0 & 0.3 & 0.7 & 1.7 & 0.08 \\
\hline Benzo(g,h.i) perylene & 0 & 0 & 0 & 1.6 & 0.29 \\
\hline Indeno(1,2,3-cd)pyrene & 0 & 0 & 0 & 0 & 0 \\
\hline Total & 4.8 & 2.78 & 5.6 & 16.5 & 0.51 \\
\hline
\end{tabular}

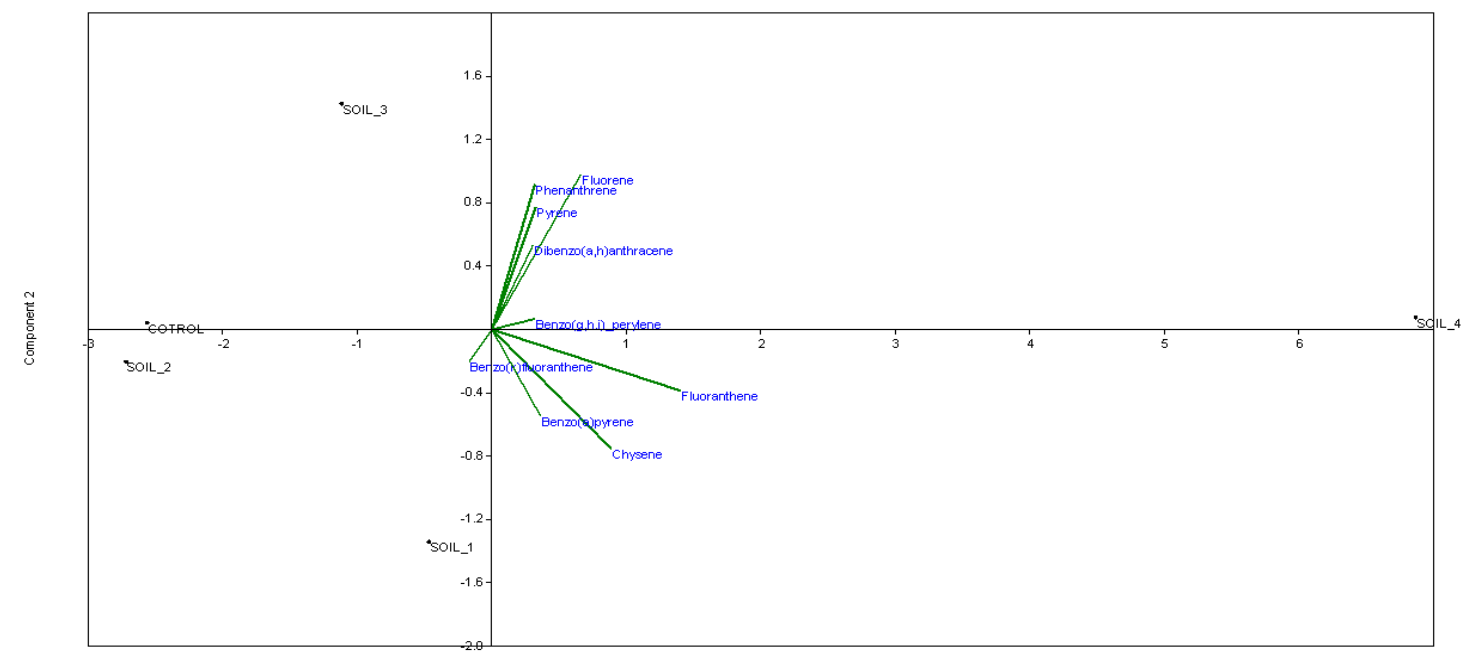

Component 1

Fig 2: Principle Component Analysis (PCA) biplot of control and polluted soil samples (soil1-4). Points represent levels of environmental variables (PAHs).

\section{REFERENCES}

Abduls- Salem, N (2009). Assessment of heavy metal pollution in dump sites in Ilorin metropolis. Ethiopian Journal of Environmental Studies and Management; 2(2): 92 - 99.

Abrajano, TA., Yan B; O’Malley, V (2003). Higher molecular weight petrogenic and pyrogenic hydrocarbons in aquatic environment. In: Sherwood Lollar B(Ed). Environmental Geochemistry, Treatise on Geochemistry, Elsevier; 9: 475-509.
Akpoveta, OV; Osakwe, SA; Okoh, BE; Otuya, BO (2010). Physicochemical Characteristics and Levels of Some Heavy Metals in Soils around Metal Scrap Dumps in Some Parts of Delta State, Nigeria Journal of Applied Science and Environmental Management; 14(4): 57 - 60.

Barnett, HL; Hunter, BB (1975). Illustrated Genera of Imperfect Fungi $3^{\text {rd }}$ ed. Minneapolis, Minn; Burgess Publishing Company 218pp. 
Cheesbrough M (2006). District Laboratory Practice in Tropical Countries. Cambridge University press, Cambridge,

Cullimore, DR (2000) Practical Atlas for Bacterial Identification. CRC Press.

Eze, VC; Omeh, YN; Ugweje, CD (2013). Microbiological and Physicochemical Assessment of Soil Contaminated with Lairage Effluent in Umuahia, Abia State, Nigeria. Journal of Pharmacy and Biological Sciences; 8(2): $50-56$.

Fawole, M; Oso, B (2001). Laboratory Manual of Microbiology. Ibadan: Spectrum Books Limited. 79pp.

Gbadebo AM, Taiwo AM, Eghele U (2010) Environmental impacts of drilling mud and cutting wastes from the Igbokoda onshore oil wells, Southern Nigeria. Indian Journal of Science and Technology 3(5): 504-510.

Imarhiagbe, EE, Atuanya, EI; Osarenotor, O (2015) Environmental evaluation of the drill cuttings at Ologbo oilfield wells, Edo State, Nigeria: a case study of its microbiological and heavy metals composition. Journal of the Nigerian Society for Experimental Biology 15 (2):50 - 57

Obi, ME (2000). Soil Physics. A Compendium of Lectures. University of Nigeria Nsukka, Nigeria. $103 \mathrm{p}$.

Odu, CTI; Esuruoso, OF., Nwoboshi, LC; Ogunwale, JA (1985). Environmental Study of the Nigerian.
Agip Oil Company, Operational Area. Soil and Fresh Water Vegetation. Milan: Union Graft Publishing; 21 - 25 .

Ogbemudia, FO; Mbong, EO (2013). Soil reaction $(\mathrm{pH})$ and heavy metal index of dumpsites within Uyo municipality Merit Research Journal of Environmental Science and Toxicology; 1(4) 82 -85 .

Onyeonwu, RO (2000). Manual for Waste/Wastewater, Soil/ Sediment, Plant and Fish analysis. MacGill Environmental Research Laboratory Manual. Benin City, 81 pp.

Osazee, OJ; Obayagbona, ON; Daniel, EO (2013) Microbiological and physicochemical analyses of top soils obtained from four municipal waste dumpsites in Benin, Nigeria International Journal of Microbiology and Mycology; 1(1) 23 -30 .

United States Department of Agriculture (USDA), Natural Resources Conservation Service (NRCS) (2000): Heavy Metal Soil Contamination. Soil Quality Institute 411 S. Donahue Dr. Auburn, AL. 36832 334-844-4741 X-177 Soil quality urban technical note No.3. 2000

Voroney, RP (2007). The soil habitat. In: Eldor AP, (Ed.) Soil Microbiology, Ecology and Biochemistry. Third edition. New York: Elsevier, $25-49$. 